\title{
High affinity of cadmium and copper to head kidney of common carp (Cyprinus carpio L.)
}

\author{
Elżbieta Kondera • Katarzyna Lugowska • \\ Piotr Sarnowski
}

Received: 11 February 2013/Accepted: 3 June 2013/Published online: 12 June 2013

(C) The Author(s) 2013. This article is published with open access at Springerlink.com

\begin{abstract}
The aim of the present study was to evaluate bioaccumulation of metals in various tissues of the freshwater fish Cyprinus carpio L. exposed to cadmium and copper (a xenobiotic and a microelement). The fish were subjected to short-term $(3 \mathrm{~h}, \mathrm{Cd}$ $\mathrm{S}$ and $\mathrm{Cu}-\mathrm{S}$ ) or long-term (4 weeks, $\mathrm{Cd}-\mathrm{L}$ and $\mathrm{Cu}-\mathrm{L}$ ) exposures to $100 \% 96 \mathrm{hLC}_{50}$ or $10 \% 96 \mathrm{hLC}_{50}$, respectively. Blood, gill, liver, head and trunk kidney were isolated weekly from 5 fish of each group for 4 weeks (post-short-term exposure and during longterm exposure). Atomic absorption spectrophotometry technique was applied to measure concentrations of metals $(\mathrm{Cd}$ and $\mathrm{Cu})$ in fish tissues. Initial concentrations of copper in fish tissues were higher than levels of cadmium. Cadmium and copper levels increased in all tissues of metal-exposed fish. After short-term exposures (at higher concentration) and during longterm exposures (at lower concentration), similar changes in metal concentrations were observed. The values of accumulation factor (ratio of final to initial metal concentration) were higher for cadmium as compared to copper. Comparison of metal levels and accumulation factors in various tissues revealed that cadmium and copper showed very high affinity to head kidney of common carp (higher than to other tissues),
\end{abstract}

E. Kondera $(\varangle) \cdot$ K. Ługowska $\cdot$ P. Sarnowski Department of Animal Physiology, University of Natural Sciences and Humanities, Prusa 12, 08-110 Siedlce, Poland

e-mail: konderae@uph.edu.pl but accumulation factors for cadmium in trunk, head kidney and liver were much higher than for copper. The concentrations of copper in organs of $\mathrm{Cu}$-exposed fish increased only slightly and quickly returned to the control level, which shows that fish organism easily buffered metal level. On the other hand, concentrations of cadmium considerably increased and remained elevated for a long time which suggests that activation of mechanisms of sequestration and elimination of cadmium required more time.

Keywords Head kidney - Bioaccumulation · Cadmium · Copper $\cdot$ Fish $\cdot$ Toxicity

\section{Introduction}

In clean natural waters, concentrations of cadmium and copper are very low, but in contaminated waters, they may increase as a result of human activities. Copper-containing compounds are used in aquaculture and agriculture: e.g., pesticides, fungicides, herbicides, bactericides (Murray-Gulde et al. 2002; Carvalho and Fernandes 2006). Main source of $\mathrm{Cd}$ pollution is industry: mines and foundries, phosphate fertilizer production and electroplating wastes (Wittman and Hu 2002; Bonda et al. 2007).

Copper and cadmium are metals, which are highly toxic to aquatic animals (Jezierska and Witeska 2001; Mendez-Armenta and Rios 2007). Cadmium is a 
xenobiotic and does not play any known metabolic role. It is genotoxic, mutagenic, carcinogenic and teratogenic (Walker 2000; Gabbianelli et al. 2003; Cavas et al. 2005). On the other hand, copper is an important essential element involved in various metabolic processes, e.g., neurotransmitter function, iron absorption from the intestine or synthesis of hemoglobin-it plays an important role in production of red blood cells (erythropoiesis), it is also a component of many enzymes (Fedeli et al. 2010). Both copper shortage and excess exert adverse effects on organisms. However, the boundary between necessary and toxic concentration of copper is difficult to determine, because toxic potential of metals depends on many factors: physiochemical properties of aquatic environment, fish health or age- and species-specific sensitivity to intoxication (Bozhkov et al. 2010).

Metals get to fish organism different ways: directly from water by gills and skin or by alimentary tract (with food). Most of metal absorbed by fish organism is transported within the body by blood (Pelgrom et al. 1995; Akahori et al. 1999; Bonda et al. 2007). The largest quantities of cadmium and copper are accumulated in metabolically active tissues (e.g., liver, kidney, alimentary tract, spleen), where thay are bound to metallothioneins-MT (Kito et al. 1982; Roesijadi 1994, Roesijadi et al. 1996; Pelgrom et al. 1995; Castano et al. 1998; Hermesz et al. 2001; Calta and Canpolat 2006; Rose et al. 2006; Panchanathan and Vattapparumbil 2006; Wu et al. 2007; Asagba et al. 2008; Dang et al. 2009; Kovarova et al. 2009). The MT plays an important role in the homeostasis of essential metals such as $\mathrm{Cu}$ and $\mathrm{Zn}$ and the sequestration of nonessential metals, like $\mathrm{Cd}$ and $\mathrm{Hg}$ (Coyle et al. 2002). MT containing about 25-35\% cysteine, due to which they have high binding capacity for metals. All SH-groups may bind a metal ion; however, about $50 \%$ of metal-binding sites are always saturated with Zn. One MT molecule can sequester 6-7 cadmium molecules (Hamer 1986). Two MT isoforms corresponding to classes MT-1 and MT-2 were isolated from the kidney and hepatopancreas of the common carp (Kito et al. 1986; Hermesz et al. 2001). Metal accumulation depends on tissue metabolism and other factors such as dose of metal, time of exposure, chemical form of metal or species and age of fish (Bielmyer et al. 2006; Bonda et al. 2007).

Accumulation of cadmium and copper in fish tissues has been extensively studied by many authors (e.g., De Conto Cinier et al. 1997; Kraemer et al. 2005; Calta and Canpolat 2006; Celechovska et al. 2007; Karaytug et al. 2007; Singh et al. 2008; Vinodhini and Narayanan 2008; Rauf et al. 2009), but affinity of metals to head kidney (pronephros) and their toxicity to this organ are almost unknown (Garofano and Hirshfield 1982; Ghosh et al. 2007; Som et al. 2009; Kondera and Witeska 2012).

Head kidney plays an important role as main hematopoietic organ in most teleost fishes (Fange 1994; Houston et al. 1996; Fijan 2002a, b; Romano et al. 2002; Moritomo et al. 2004; Rombout et al. 2005; Gangopadhyay and Homechaudhuri 2011). Pronephros functions also as a secondary lymphoid organ in which large numbers of antibody producing cells reside. Moreover, production of corticosteroids and catecholamines (hormone participating in stress response) takes place in head kidney (Wendelaar Bonga 1997; Hontela 1998). Therefore, hematopoietic, immune and endocrine functions are combined in pronephros (Wendelaar Bonga 1997; Weyts et al. 1999), thus cadmium and copper accumulation in head kidney can produce toxic effects on many important physiological processes in fish. Subletalne concentrations of both metals can change hormone levels (Hontela 1998; LizardoDaudt et al. 2007; Ramesh et al. 2007; Dangre et al. 2010), immunological mechanisms (Petanova et al. 2000; Jelovcan et al. 2003; Lafuente et al. 2004) or hematological parameters (Kondera and Witeska 2012; Witeska et al. 2010, 2011).

The aim of the present study was to evaluate the bioaccumulation of metals in the most important tissues participating in uptake, transport, metabolism and excretion of metals (blood, gill, liver and trunk kidney), and the head kidney as a key hematopoietic organ of the fresh water Cyprinus carpio L. exposed to cadmium and copper.

\section{Materials and methods}

Six-month-old carp juveniles (C. carpio L.) of body mass $21.6 \pm 8.3 \mathrm{~g}$ were harvested in autumn from the rearing pond of the Inland Fisheries Institute in Żabieniec. At the Department of Animal Physiology, University of Natural Sciences and Humanities in Siedlce the fish were acclimated for a month to the laboratory conditions in the flow-through aerated tank, at the temperature $17-18{ }^{\circ} \mathrm{C}$ (dissolved oxygen 
level $66-87 \%$ of saturation, concentration of $\mathrm{NO}_{2}{ }^{-} 0.02-0.06 \mathrm{mg} / \mathrm{dm}^{3}$ and $\left.\mathrm{NH}_{4}{ }^{+} 4.6-7.1 \mathrm{mg} / \mathrm{dm}^{3}\right)$. The fish were fed Aller Classic $4 \mathrm{~mm}$ pellets $(30 \%$ protein, $7 \%$ fat, $43 \%$ carbohydrate, $7 \%$ ash, $5 \%$ fiber) once a day at the rate of $2 \%$ of body mass/day. Then, the fish were transferred to $100 \mathrm{dm}^{3}$ aerated aquaria (10 fish in each) and fed Aller Aqua Classic $4 \mathrm{~mm}$ (1\% of stock mass/day, once a day before water renewal). Every day three-fourth of water was renewed without disturbing fish. Prior to the experiment, 96-h survival tests were performed, and $96 \mathrm{hLC}_{50}$ values were calculated using the probit method for both metals. Concentrations used in the experiment were based on $96 \mathrm{hLC}_{50}$ values to ensure the same toxic power of both metals. The fish were subjected to short-term exposures (3-h exposure to $6.5 \mathrm{mg} / \mathrm{dm}^{3}$ cadmium or $0.75 \mathrm{mg} / \mathrm{dm}^{3}$ copper$100 \%$ of $96 \mathrm{hLC} 50$ - groups $\mathrm{Cd}-\mathrm{S}$ and $\mathrm{Cu}-\mathrm{S})$ and long-term exposures (4-week exposure to $0.65 \mathrm{mg} / \mathrm{dm}^{3}$ cadmium or $0.075 \mathrm{mg} / \mathrm{dm}^{3}$ copper $-10 \%$ of 96hLC50-groups $\mathrm{Cd}-\mathrm{L}$ and $\mathrm{Cu}-\mathrm{L}$ ). Experimental solutions were made using $\mathrm{CdCl}_{2} \times 2 \frac{1}{2} \mathrm{H}_{2} \mathrm{O}$ and $\mathrm{CuSO}_{4} \times 5 \mathrm{H}_{2} \mathrm{O}$. Control group was kept in clean tap water $\left(0.3-1 \mu \mathrm{g} / \mathrm{dm}^{3}\right.$ of $\mathrm{Cd}, 2-33 \mu \mathrm{g} / \mathrm{dm}^{3}$ of $\mathrm{Cu}$, $\mathrm{pH}$ 7.5-7.6, hardness $179-198 \mathrm{mg} / \mathrm{dm}^{3} \mathrm{CaCO}_{3}$ ).

Blood $\left(1 \mathrm{~cm}^{3}\right)$, main hematopoietic organ-head kidney and the most important organs participating in uptake, transport, metabolism and excretion of metals (gill, liver and trunk kidney) were sampled weekly for 1 month from 5 fish from each metal-exposed group (total number of fish $=80$ ), and 10 fish in control group. The separated tissues were weighed (the laboratory weight Radwag the wax 40/160 No. 103440) and dried for $48 \mathrm{~h}$ at $70{ }^{\circ} \mathrm{C}$. Dried tissues were manually ground in the mortar, transferred to beakers and dissolved in $2 \mathrm{~cm}^{3}$ of $69 \% \mathrm{HNO}_{3}$ (the Trace the Pur, Merck). After $24 \mathrm{~h}, 1 \mathrm{~cm}^{3}$ of $33 \% \mathrm{H}_{2} \mathrm{O}_{2}$ (Trace Pur, Merck) was added, and the samples were heated for $1 \mathrm{~h}$ to boiling in water baths to complete mineralization of tissues. Then, the concentrations of copper (using AAS flame method) and cadmium (using ETAAS method with electrothermal atomization) were measured in all samples in the atomic absorption spectrophotometer (the AAS-30 the Zeiss) in the Institute of Chemistry of Siedlce University of Natural Sciences and Humanities (Oprządek et al. 2006, 2010). Concentrations of metals in fish tissues were calculated according to calibration curves $(0.001-0.1 \mu \mathrm{g} \mathrm{Cd} / \mathrm{ml}$ and $0.1-0.25 \mu \mathrm{g} \mathrm{Cu} / \mathrm{ml})$. For copper, 1-2 replicates of each sample were analyzed, while for cadmium 3-5. Accuracy and precision of methods applied were evaluated using prawn certified reference materials (GBW 08572). The results showed good accordance with the certified values (93-103\%). Concentrations of metals in fish tissues were calculated per $1 \mathrm{~g}$ of fresh mass of each organ, and the results were given as $\mu \mathrm{g} / \mathrm{g}$ wet weight. Cadmium and copper accumulation factors-A (the ratio of final to initial metal concentration) were also calculated.

The obtained results were subjected to statistical analysis using the nonparametric $U$ Mann-Whitney test, assuming that differences were significant at $p \leq 0.05$.

The study obtained agreement of the III Local Ethical Committee at the Warsaw University of Life Sciences (No. 41/2008).

\section{Results}

In tissues of fish from the control group, the level of copper was $3.1-38.7 \mu \mathrm{g} / \mathrm{g}$, while concentrations of cadmium were much lower: $0.1-3.6 \mu \mathrm{g} / \mathrm{g}$. Concentrations of both metals in the control group were the highest in head kidney, while the lowest levels were observed in trunk kidney $(\mathrm{Cd})$ and gill $(\mathrm{Cu})$.

In head kidney, the level of cadmium (Table 1) considerably increased in 1 week after short-term exposure and reached the maximum level: $461.7 \mu \mathrm{g} / \mathrm{g}$ $(\mathrm{A}=127.2)$, then gradually decreased and in 4 weeks the value was similar as in the control (Fig. 1). In fish subjected to long-term $\mathrm{Cd}$-exposure cadmium concentration increased until the 2 weeks $(\mathrm{A}=37.4)$, and then decreased, but remained elevated above the control level until the end of experiment. A significant increase in level of copper (Table 2) was noted only in 4 weeks after short-term exposure $(\mathrm{A}=2.5)$ and in 2 weeks of long-term exposure $(\mathrm{A}=1.9)$.

Both short- and long-term exposures of fish in cadmium-contaminated water (Table 1) caused a strong increase in the level of this metal in liver in 1 week of the experiment: Cd-S1 $(\mathrm{A}=22.8)$ and $\mathrm{Cd}-\mathrm{L} 1$ (A = 33.1) group. Despite a downward tendency, elevated levels of $\mathrm{Cd}$ were observed until the end of the experiment (Fig. 2). The increase in copper concentration took place in 2 last weeks of short-term exposure $(\mathrm{A}=1.8$ in $\mathrm{Cu}-\mathrm{S} 3$ and $\mathrm{A}=1.3$ in $\mathrm{Cu}-\mathrm{S} 4)$ Table 2. 
Table 1 Cadmium accumulation factors-A (ratio of final to initial metal concentration) in tissues of common carp over 4 weeks post 3-hour exposure to $6.5 \mathrm{mg} / \mathrm{dm}^{3}$ of cadmium
(96hLC50)—Cd-S1, Cd-S2, Cd-S3, Cd-S4 and during 4-week exposure to $0.65 \mathrm{mg} / \mathrm{dm}^{3}$ of cadmium (10\% 96hLC50)-CdL1, Cd-L2, Cd-L3, Cd-L4

\begin{tabular}{lrrrrrrrr}
\hline Tissues & \multicolumn{1}{l}{ Experimental groups } & & & & \\
\cline { 2 - 8 } & Cd-S1 & Cd-S2 & Cd-S3 & Cd-S4 & Cd-L1 & Cd-L2 & Cd-L3 & Cd-L4 \\
\hline Head kidney & 127.2 & 20.2 & 1.7 & 1.1 & 25.6 & 37.4 & 4.4 & 2.2 \\
Liver & 22.8 & 13.4 & 2.3 & 1.3 & 33.1 & 14.7 & 2.3 & 1.5 \\
Trunk kidney & 78.5 & 129.8 & 25.1 & 52.8 & 73.1 & 91.5 & 8.9 & 40.4 \\
Gill & 8.7 & 6.8 & 2.2 & 1.2 & 5.8 & 4.6 & 1.5 & 1.1 \\
Blood & 19.4 & 17.9 & 4.4 & 1.1 & 18.6 & 12.6 & 2.5 & 1.5 \\
\hline
\end{tabular}

Table 2 Copper accumulation factors-A (ratio of final to initial metal concentration) in tissues of common carp over 4 weeks post 3 -hour exposure to $0.75 \mathrm{mg} / \mathrm{dm}^{3}$ of copper
(96hLC50)—Cu-S1, Cu-S2, Cu-S3, Cu-S4 and 4-week exposure to $0.075 \mathrm{mg} / \mathrm{dm}^{3}$ of copper (10\%96hLC50)- $\mathrm{Cu}-\mathrm{L} 1, \mathrm{Cu}-$ $\mathrm{L} 2, \mathrm{Cu}-\mathrm{L} 3, \mathrm{Cu}-\mathrm{L} 4$

\begin{tabular}{lllllllll}
\hline Tissues & \multicolumn{2}{l}{ Experimental groups } & & & & \\
\cline { 2 - 8 } & Cu-S1 & Cu-S2 & Cu-S3 & Cu-S4 & Cu-L1 & Cu-L2 & Cu-L3 & Cu-L4 \\
\hline Head kidney & 1.2 & 1.5 & 2.5 & 2.5 & 1.8 & 1.9 & 1.8 & 1.5 \\
Liver & 0.6 & 0.9 & 1.8 & 1.3 & 1.0 & 1.4 & 1.3 & 1.3 \\
Trunk kidney & 0.8 & 1.0 & 1.1 & 1.2 & 0.9 & 1.0 & 1.3 & 1.4 \\
Gill & 0.8 & 0.9 & 1.2 & 1.1 & 2.3 & 2.3 & 2.4 & 1.1 \\
Blood & 0.8 & 0.9 & 0.9 & 0.6 & 0.8 & 1.1 & 1.1 \\
\hline
\end{tabular}

In trunk kidney (Fig. 3) cadmium concentration increased till 2 weeks when it reached a maximum in Cd-S2 (A = 129.8) and Cd-L2 (A = 91.5). In 3 weeks, a decrease was noted, though $\mathrm{Cd}$ concentration was still considerably higher than in the control group $(2.5 \mu \mathrm{g} / \mathrm{g}$ in Cd-S3 and $0.9 \mu \mathrm{g} / \mathrm{g}$ in Cd-L3). In the last week of the experiment, concentrations of cadmium in trunk kidney increased again (Cd-S4-5.3 $\mu \mathrm{g} / \mathrm{g}, \mathrm{Cd}-\mathrm{L} 4-4.0 \mu \mathrm{g} / \mathrm{g}$ ). In case of copper, only the long-term exposure caused significant increase in metal level in trunk kidneys in 3 and 4 weeks (to $11.7 \mu \mathrm{g} / \mathrm{g}$ in $\mathrm{Cu}-\mathrm{L} 4$ ).

The maximum cadmium levels in fish gills were observed in the first week of the experiment (in Cd-S1 and Cd-L1, respectively: $\mathrm{A}=8.7$ and $\mathrm{A}=5.8$ )—Table 1 . Then cadmium content in gills decreased, but only in Cd-L4 group returned to the control level, while in Cd$\mathrm{S} 4$ remained elevated (Fig. 4). Significant increase in $\mathrm{Cu}$ level was noted in fish subjected to long-term exposure to this metal $(\mathrm{A}=2.3-3.2)$ - Table 2 .

Short-term as well as long-term cadmium exposures caused significant increase in concentrations of this metal in peripheral blood in 1 week $(\mathrm{A}=19.4$ in $\mathrm{Cd}-\mathrm{S} 1, \mathrm{~A}=18.6$ in Cd-L1) - Table 1. In the subsequent weeks, Cd concentrations gradually decreased and returned to initial level in 4 weeks (Cd-S4, Cd-L4). Blood of fish subjected to copper concentrations of this metal did not significantly increase $(\mathrm{A}=0.8-1.1)$, and even a significant drop of $\mathrm{Cu}$ concentration (to $2.5 \mu \mathrm{g} / \mathrm{g}$ ) was observed in Cd-S4 group (Fig. 5).

\section{Discussion}

The obtained results show that initial concentrations of copper in fish tissues were higher than the levels of cadmium. According to various authors, cadmium concentration in freshwater fish tissues (intestine, muscles, kidney, gill, skin, spleen, brain, liver) usually does not exceed $2 \mu \mathrm{g} / \mathrm{g}$ (Kraal et al. 1995; Hollis et al. 1999; Panchanathan and Vattapparumbil 2006; Wu et al. 2007; Singh et al. 2008; Tao et al. 2008; Vinodhini and Narayanan 2008; Dang et al. 2009; Isani et al. 2009). According to Calta and Canpolat (2006), natural level of copper in the tissues of cyprinid fishes (C. carpio, Acanthobrama marmit, Chondrostoma regium) were in muscles below $5 \mu \mathrm{g} / \mathrm{g}$, 

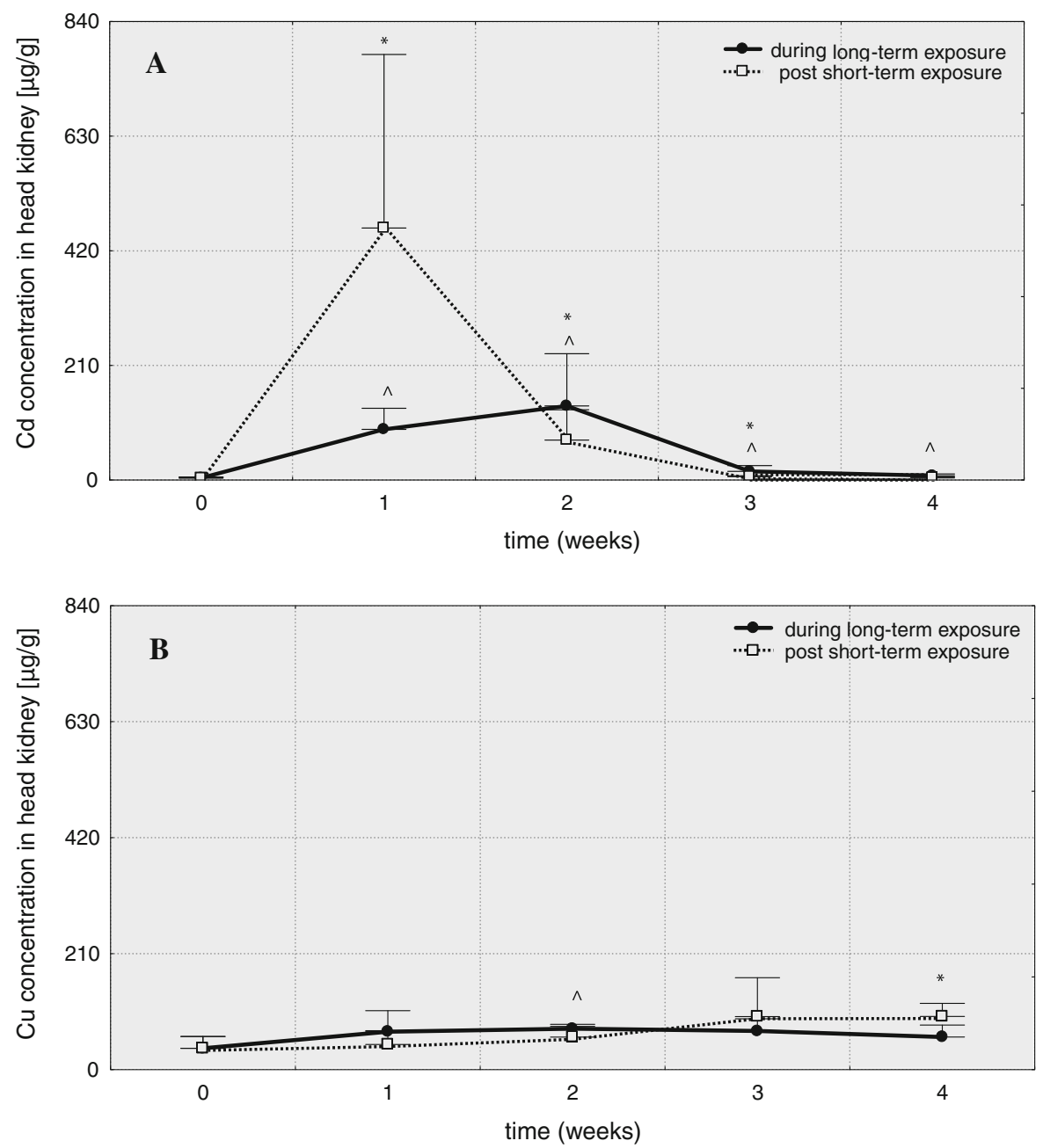

Fig. 1 Cadmium (A) and copper (B) concentrations in head kidney of common carp $(\mu \mathrm{g} / \mathrm{g})$ over 4 weeks post 3-hour exposure to $6.5 \mathrm{mg} / \mathrm{dm}^{3}$ of cadmium or $0.75 \mathrm{mg} / \mathrm{dm}^{3}$ of copper (96hLC50) and 4-week exposure to $0.65 \mathrm{mg} / \mathrm{dm}^{3}$ of cadmium or

in gill $5-10 \mu \mathrm{g} / \mathrm{g}$, in skin near $10 \mu \mathrm{g} / \mathrm{g}$, in gonads $5-20 \mu \mathrm{g} / \mathrm{g}$, and in liver $15-30 \mu \mathrm{g} / \mathrm{g}$. Higher natural level of copper in fish in comparison with cadmium obviously results from the fact that $\mathrm{Cu}$ is a microelement and thus - natural component of body involved in metabolic processes, while cadmium is a xenobiotic (Ghedira et al. 2010).

Both, after short-term and long-term exposures in water contaminated with cadmium and copper, the levels of metals in carp tissues were considerably higher than their concentration in water which indicates bioaccumulation of these elements in fish organism. Also Radhakrishnan (2010) observed that
$0.075 \mathrm{mg} / \mathrm{dm}^{3}$ of copper and (10\% 96hLC50), *values significantly different from the control (short-term exposures), ${ }^{\wedge}$ values significantly different from the control (long-term exposures), test $U, p \leq 0.05, n=5$

levels of metals ( $\mathrm{Fe}, \mathrm{Cu}, \mathrm{Zn}, \mathrm{Mn}, \mathrm{Cr}$ ) in Heteropneustes fossilis gill, liver and muscle were higher than in water. Olowoyo et al. (2011) reported that concentrations of $\mathrm{Zn}, \mathrm{Fe}, \mathrm{Mn}, \mathrm{Cr}, \mathrm{Ni}, \mathrm{Cu}, \mathrm{Pb}$ in $C$. carpio and Clarias gariepinus liver, gill, muscle, bone were higher compared to the levels of these metals in water and concluded that it was a result of bioaccumulation.

In the present work, both metals showed very high affinity to carp head kidney. Almost no data concerning concentrations of metals in this organ are available in the literature. Garofano and Hirshfield (1982) observed accumulation of cadmium in spleen and head kidney of Ictalurus nebulosus. However, 

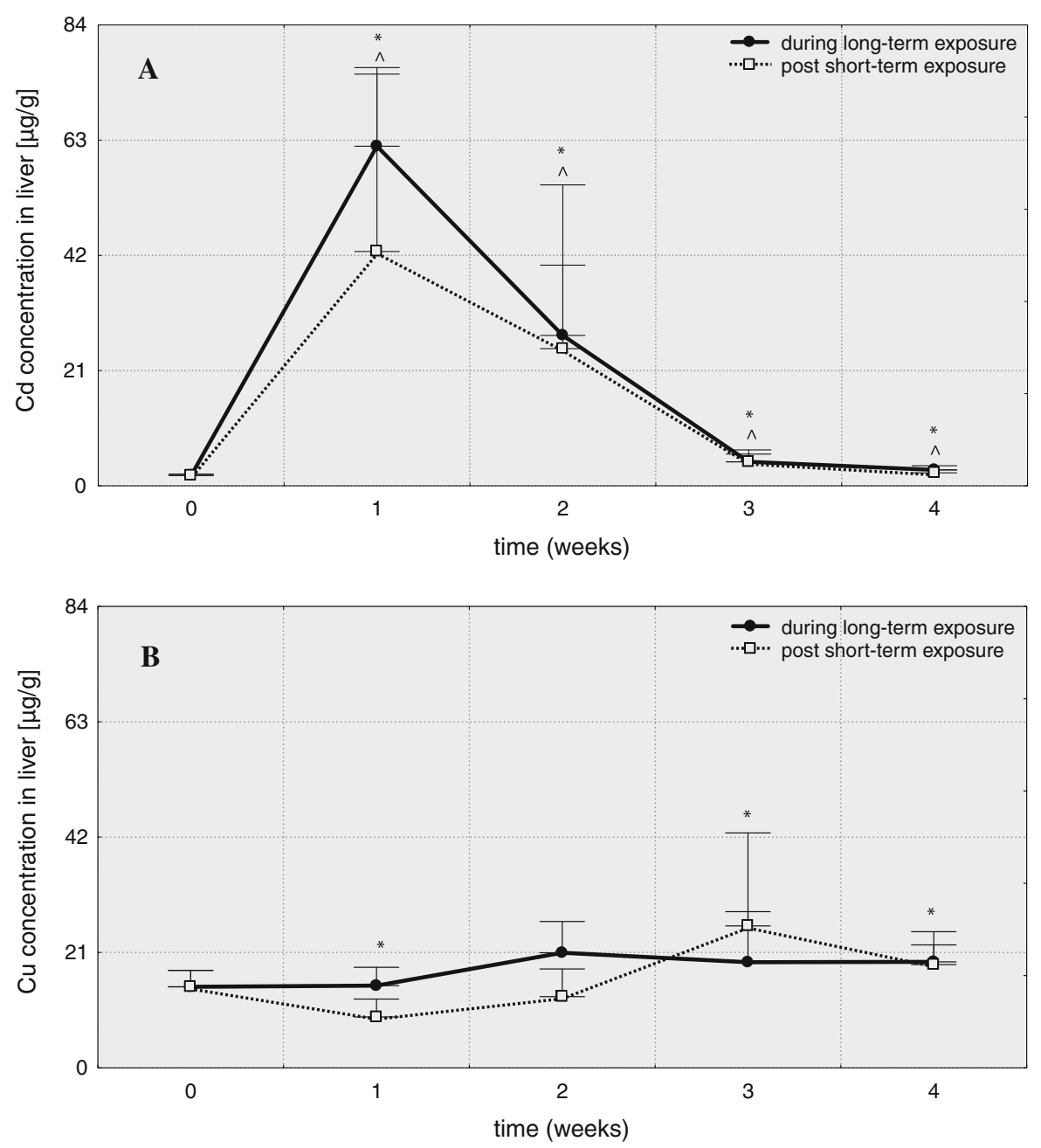

Fig. 2 Cadmium (A) and copper (B) concentrations in liver of common carp $(\mu \mathrm{g} / \mathrm{g})$ over 4 weeks post 3 -hour exposure to $6.5 \mathrm{mg} / \mathrm{dm}^{3}$ of cadmium or $0.75 \mathrm{mg} / \mathrm{dm}^{3}$ of copper (96hLC50) and 4-week exposure to $0.65 \mathrm{mg} / \mathrm{dm}^{3}$ of cadmium or

Woodling et al. (2001) observed that cadmium and copper were accumulated mainly in fish trunk kidney, while their concentrations in head kidney were considerably lower.

High affinity to head kidney can be source of metalinduced alterations in fish hematopoietic system. Garofano and Hirshfield (1982) reported destruction or elimination of all hematopoietic elements (except for mature erythrocytes) in pronephros of cadmium-intoxicated Ictalurus nebulosus. Also Saxena et al. (1992) mentioned damage of Heteropneustis fossilis hematopoietic tissue caused by this metal. Cadmium was found to downregulate $\mathrm{Hb}$ and Epo expression in Cyprinodon variegatus larvae under hypoxic conditions (Dangre
$0.075 \mathrm{mg} / \mathrm{dm}^{3}$ of copper (10\%96hLC50), *values significantly different from the control (short-term exposures), ^values significantly different from the control (long-term exposures), test $U, p \leq 0.05, n=5$

et al. 2010) which indicates inhibitory effect on erythropoiesis. Changes in hematopoietic activity were also observed in $\mathrm{Cu}$-exposed Labeo rohita (Som et al. 2009). Sublethal exposure induced an increase in frequency of erythropoietic and leukopoietic precursor cells, while at lethal conditions, a decrease occurred at the beginning of exposure and was followed by an increase. Som et al. (2009) also reported an increase in frequency of blast cells in copper-exposed Labeo rohita, and an increase in apoptotic rate of hematopoietic precursors, while proliferation rate was elevated under sublethal conditions and reduced in fish subjected to lethal exposure. Cadmium and copper can also induce endocrine disruption in head kidney. According 

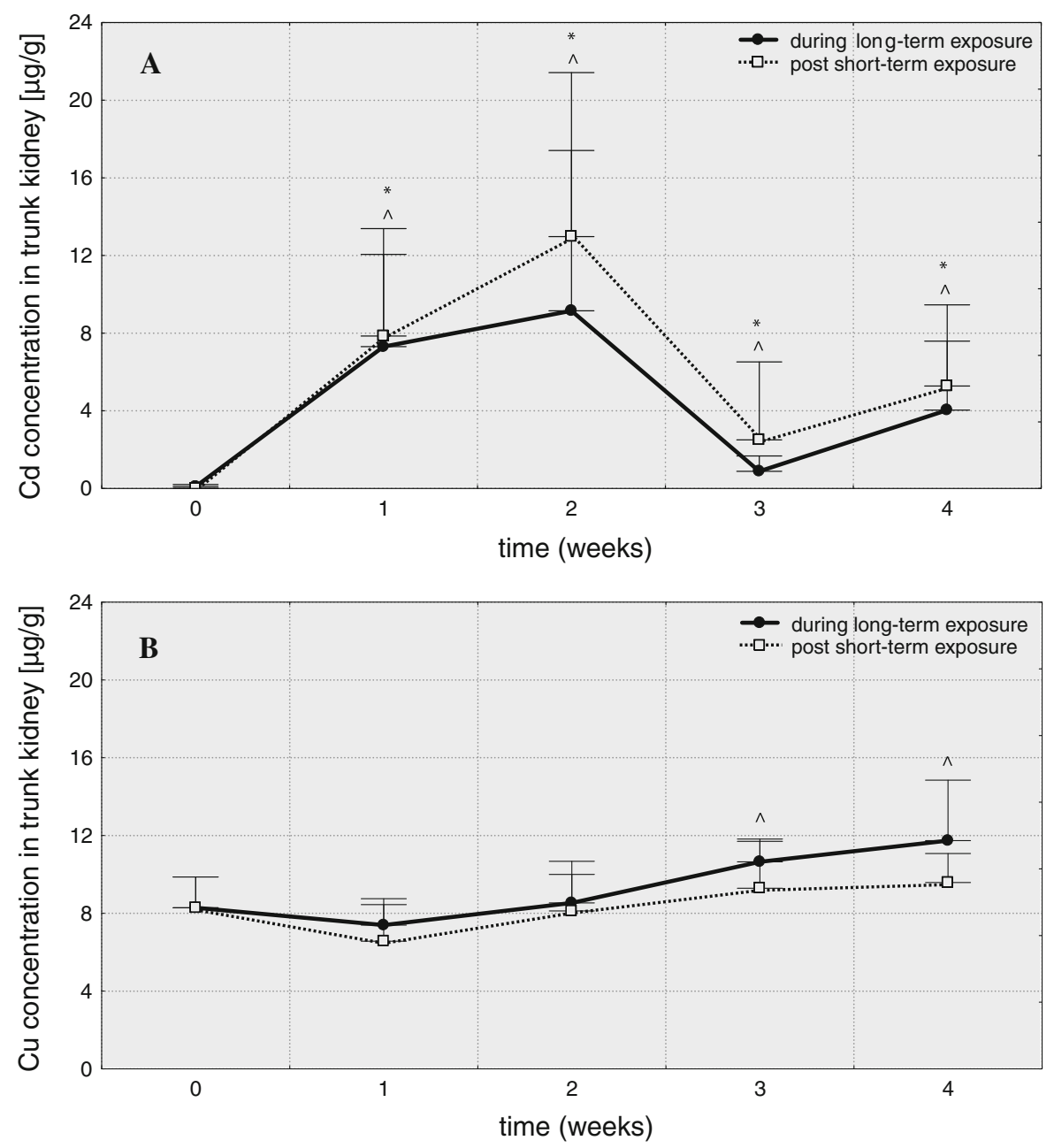

Fig. 3 Cadmium (A) and copper (B) concentrations in trunk kidney of common carp $(\mu \mathrm{g} / \mathrm{g})$ over 4 weeks post 3-hour exposure to $6.5 \mathrm{mg} / \mathrm{dm}^{3}$ of cadmium or $0.75 \mathrm{mg} / \mathrm{dm}^{3}$ of copper (96hLC50) and 4-week exposure to $0.65 \mathrm{mg} / \mathrm{dm}^{3}$ of cadmium or

to Lizardo-Daudt et al. (2007), a significant drop of cortisol concentration was observed in Oncorhynchus mykiss head kidney exposed in vitro to $\mathrm{CdCl}_{2}$. Also Hontela (1998) noted a decrease in plasma cortisol level of Perca flavescens exposed to cadmium. Significant increase in plasma cortisol and prolactin level of C. carpio subjected to acute and sublethal copper treatments was reported by Ramesh et al. (2007).

This study revealed also that copper content in tissues of fish exposed to this metal increased less than cadmium (taking into consideration the difference between concentrations of both metals in water), which indicates that the organism efficiently buffered the level of copper. On the contrary, concentration of
$0.075 \mathrm{mg} / \mathrm{dm}^{3}$ of copper (10\%96hLC50), *values significantly different from the control (short-term exposures), ^values significantly different from the control (long-term exposures), test $U, p \leq 0.05, n=5$

cadmium considerably increased, in most cases reaching the maximum in 1 week of tests (similarly, after short-term exposure and during long-term exposure). In subsequent weeks, concentrations of cadmium decreased, but in head kidney, trunk kidney and liver, they remained elevated compared to the control until the end of the experiment. This suggests that activation of mechanisms of sequestration and elimination of cadmium required some time. The maximum concentrations and accumulation factors of cadmium were higher in comparison with copper particularly in head kidney, liver and blood, while in gill and trunk kidney, the levels of both metals were similar. 

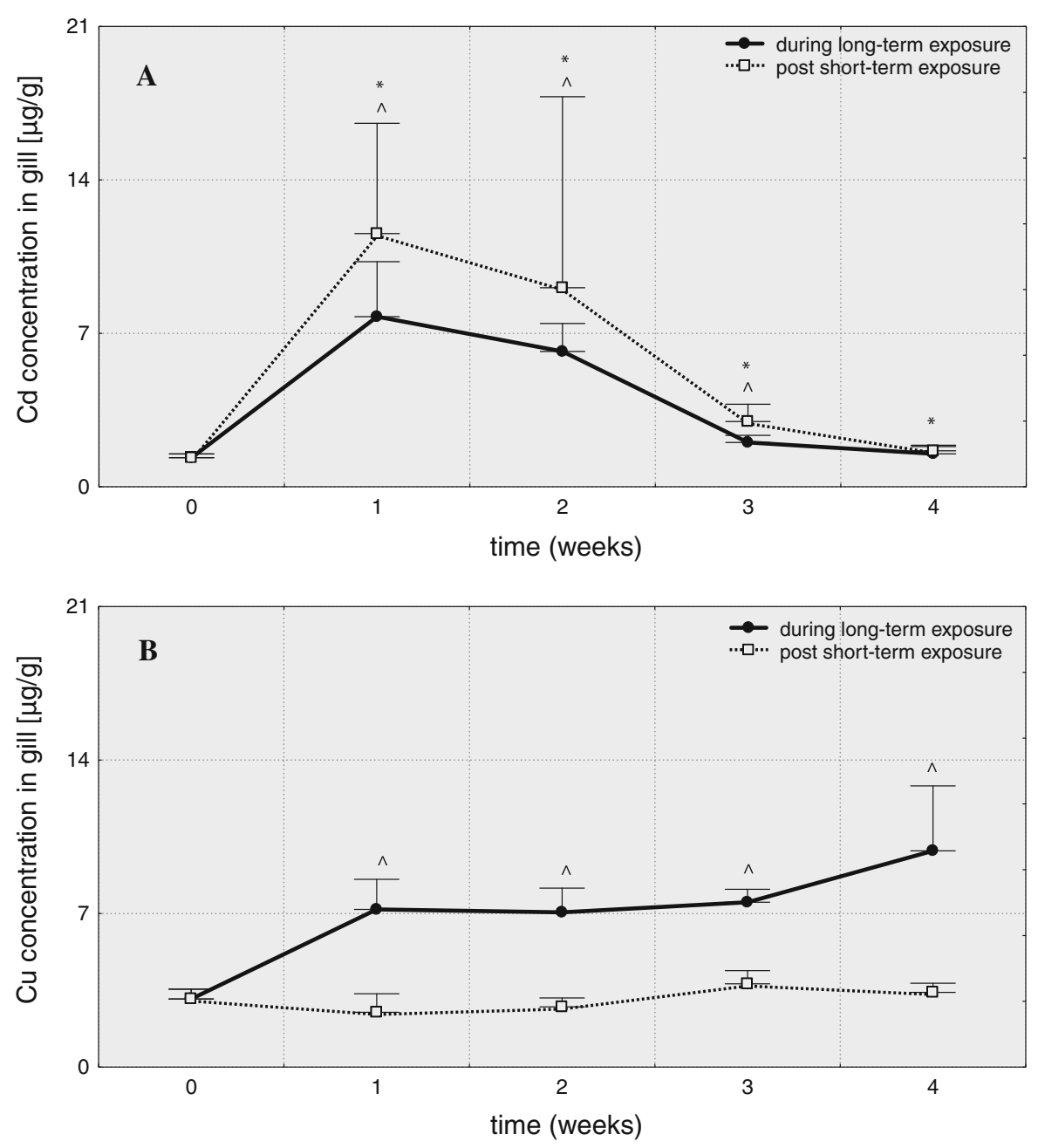

Fig. 4 Cadmium (A) and copper (B) concentrations in gill of common carp $(\mu \mathrm{g} / \mathrm{g})$ over 4 weeks post 3-hour exposure to $6.5 \mathrm{mg} / \mathrm{dm}^{3}$ of cadmium or $0.75 \mathrm{mg} / \mathrm{dm}^{3}$ of copper (96hLC50) and 4-week exposure to $0.65 \mathrm{mg} / \mathrm{dm}^{3}$ of cadmium or $0.075 \mathrm{mg} / \mathrm{dm}^{3}$ of

Al-Nagaawy (2008) reported that accumulation of essential metals $(\mathrm{Cu})$ in Oreochromis niloticus gills and muscles was lesser in comparison with xenobiotics $(\mathrm{Pb})$. Considerably higher cadmium concentration compared to copper in gills of Odontesthes bonariensis after 16-day exposures was observed by Carriquiriborde and Ronco (2008). Romeo et al. (2000) obtained similar results: After $48 \mathrm{~h}$ from injections of cadmium and copper solutions, they noted that the level of cadmium in tissues of Dicentrarchus labrax was considerably higher in comparison with the control, while concentration of copper remained unchanged. According to these authors, copper activates detoxification mechanisms of copper $(10 \% 96 \mathrm{hLC} 50)$, *values significantly different from the control (short-term exposures), ${ }^{\wedge}$ values significantly different from the control (long-term exposures), test $U, p \leq 0.05$, $n=5$

organism more efficiently than cadmium. Kraemer et al. (2005) reported higher $\mathrm{Cd}$ accumulation in comparison with $\mathrm{Cu}$ as a result of less effective elimination of this element from organism. According to Kalay and Canli (2000), lower accumulation of microelements (Cu, Zn) in relation to xenobiotics $(\mathrm{Cd}, \mathrm{Pb})$ can result from better control mechanisms of level and shorter time of half-life in organism and from lower affinity of natural components to tissues.

After short exposures, the levels of metals in some tissues still increased in several weeks after transfer of fish to clean water: The maximum $\mathrm{Cu}$ concentration in head kidney and liver was has noted in group $\mathrm{Cu}-\mathrm{S} 3$ 

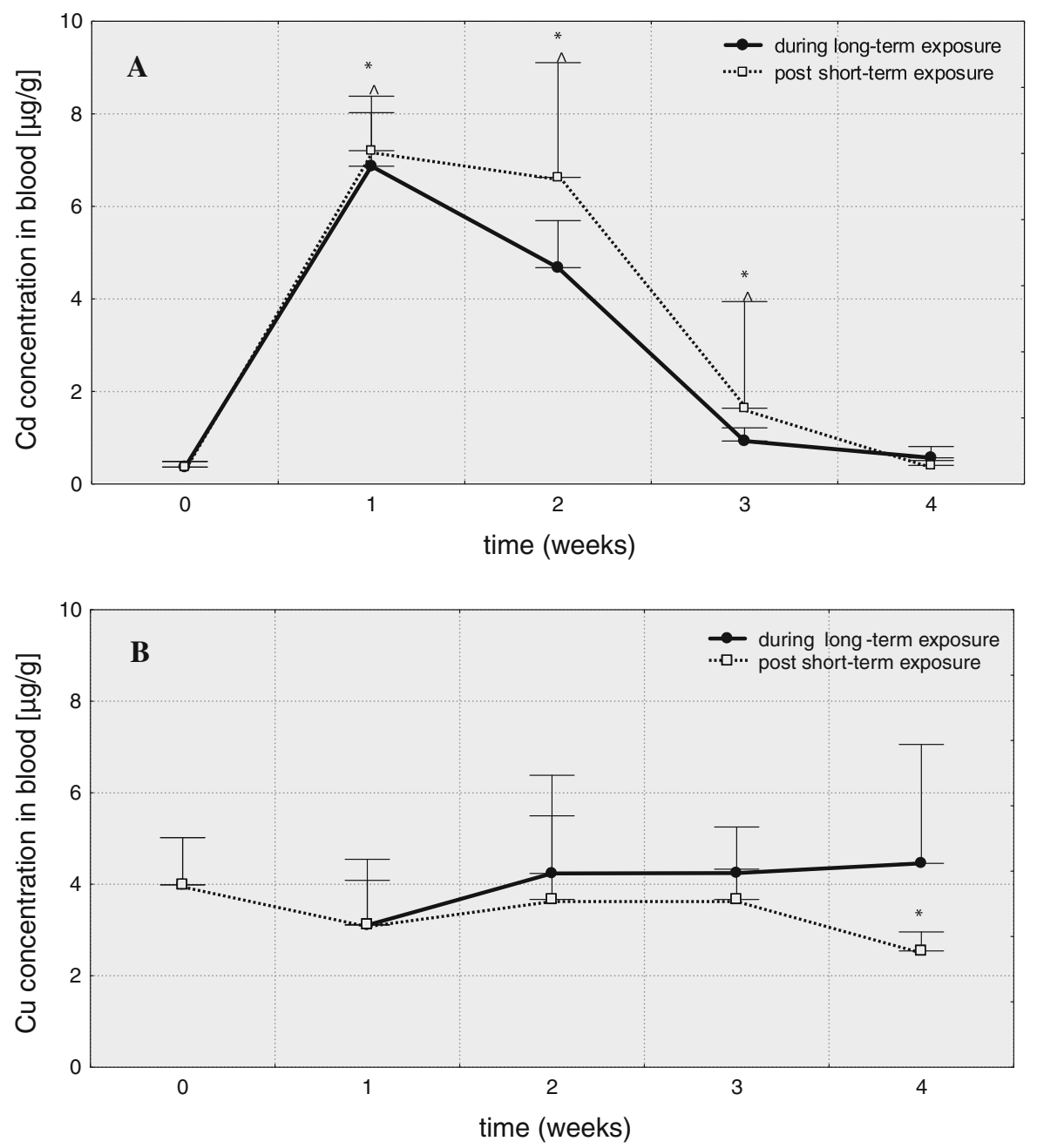

Fig. 5 Cadmium (A) and copper (B) concentrations in blood of common carp $(\mu \mathrm{g} / \mathrm{g})$ over 4 weeks post 3-hour exposure to $6.5 \mathrm{mg} / \mathrm{dm}^{3}$ of cadmium or $0.75 \mathrm{mg} / \mathrm{dm}^{3}$ of copper (96hLC50) and 4-week exposure to $0.65 \mathrm{mg} / \mathrm{dm}^{3}$ of cadmium or $0.075 \mathrm{mg} / \mathrm{dm}^{3}$ of

and in trunk kidney in $\mathrm{Cu}-\mathrm{S} 4$, while the highest level of $\mathrm{Cd}$ in trunk kidney was in group $\mathrm{Cu}-\mathrm{S} 2$. It shows that metals taken up from water were not immediately excreted but were translocated inside the organism. Various dynamics of changes of cadmium and copper levels in the tissues probably resulted from different ways of transportation and accumulation, and pathways of metabolism of each metal.

According to Kraemer et al. (2005), copper and cadmium first show affinity to gill which is main uptake site of waterborne elements, then they are transported via blood to liver and kidney. Metal ions usually accumulated less in gills since they are a temporary target organ of accumulation, and then $\mathrm{Cd}$ copper (10\% 96hLC50), *values significantly different from the control (short-term exposures), ${ }^{\wedge}$ values significantly different from the control (long-term exposures), test $U, p \leq 0.05$, $n=5$

is transferred to other organs (Wu et al. 2007). Various authors (e.g., Kraal et al. 1995; Jacobson and Reimschuessel 1998; McGeer et al. 2000; Celechovska et al. 2007; Ghedira et al. 2010; Radhakrishnan 2010; Shao et al. 2010) showed that the highest concentrations of copper were noted in fish liver. Liver being main detoxification site in organism is also an organ that bioaccumulates toxic substances, and thus, it usually shows higher concentrations of metals than another tissues (Allen 1995; Olowoyo et al. 2011). Couture and Kumar (2003) suggested that copper and cadmium concentration led to an up-regulation of liver protein metabolism, presumably at least in part for the purpose of metals detoxification. In Oncorhynchus 
mykiss, active regulation of internal $\mathrm{Cu}$ levels in response to sublethal waterborne copper, specifically an up-regulation of hepatic turnover and enhanced elimination of $\mathrm{Cu}$ via the bile, has been demonstrated by Grosell et al. (1997, 1998). Cadmium is known to disrupt hepatic carbohydrate metabolism, which leads to a decrease in glycogen storage and increased plasma glucose (Soengas et al. 1996).

Cadmium accumulates in tissues of fish easily, showing high affinity to liver and kidneys (e.g., Bentley 1991; Kock et al. 1996; Schultz et al. 1996; Dallinger et al. 1997; De Smet and Blust 2001; Thophon et al. 2003; Reynders et al. 2006; Shalaby 2007; Wu et al. 2007; Ghedira et al. 2010; Cao et al. 2012). De Conto Cinier et al. (1997) observed that Cd reached high concentration in liver earlier than in kidney in carps exposed to this metal. Similar results were obtained in the present study, both after shortterm and during long-term exposure. Bonda et al. (2007) reported that after single short exposure to high concentration of cadmium metal was accumulated mainly in liver, but long-term exposures to low concentration of this metal-induced disfunction of kidneys caused by increased accumulation of element in this organ.

A lot of pollutants dissolved in water (also metals) enter to fish organism mainly by gills (Evans et al. 1987; Leguen et al. 2007), across ion channels of respiratory epithelium or protein complex of the chloride cells in gills (Thophon et al. 2003; Galvez et al. 2007). Cadmium uptake involves competition with $\mathrm{Ca}, \mathrm{Fe}$ and $\mathrm{Zn}$ and takes place via their transport systems. According to Verbost et al. (1989), the pivotal mechanism in the cytotoxic action of $\mathrm{Cd}^{2+}$ is the inhibition of $\mathrm{Ca}^{2+}$ extrusion and disturbance of intracellular $\mathrm{Ca}^{2+}$ homeostasis which results in an increase in cytosolic $\mathrm{Ca}^{2+}$ to toxic levels. Copper is known to cause osmotic imbalance by reduction of $\mathrm{Na}^{+} / \mathrm{K}^{+}$ATPase activity (Pelgrom et al. 1995).

Large fraction of copper absorbed by fish organism is transported within the body by blood plasma bound to albumin, histidine, threonine and glutathione (Bettger et al. 1987; Pelgrom et al. 1995) and then is deposited in liver. This gland plays essential role in copper metabolism. In liver, copper is attached to ceruloplasmin. Also metallothioneins (MT) play important role in binding this metal in vertebrates. They protect against toxic action of metals by reducing the concentration of free metal ions to physiological values in the tissues (Roesijadi et al. 1996). MTcomplexes play primary function in homeostasis of copper in organism. Due to MT binding $\mathrm{Cu}$ accumulated in fish can be eliminated from blood circulation across liver quickly and efficiently. Carbonell and Trazona (1992) suggest that long-term exposures to cooper sulfate do not increase $\mathrm{Cu}$ concentrations in fish tissues but modify the relationship between cooper and other essential metals such as iron or zinc. When excess copper penetrate into cells, they are able to displace zinc from thioneins (normally present in cytosol). Copper may also bind to the sulfhydryl groups of several enzymes (e.g., glucose-6-phosphatase, glutathione reductase) thus interfering with their protection of cells from free radical damage. Depending on the level and organism's demand, copper can be stored, distributed to various tissues or eliminated (Pelgrom et al. 1995).

After absorption, ions of toxic cadmium in circulating blood are mainly absorbed by erythrocytes (they bind to proteins of cells membrane or to hemoglobin). Only a small quantity of $\mathrm{Cd}$ in blood is transported bound to albumin, cysteine or glutathione (Bonda et al. 2007). Upon entry into blood plasma, it is distributed throughout the body, with the greatest burdens in the liver and kidneys. At this time, organism activates mechanisms of detoxification (Jonsson and Part 1998). In the liver, Cd not bound to MT induces synthesis of new MT (Pelgrom et al. 1995; De Conto Cinier et al. 1997; Rose et al. 2006; Huang et al. 2007; Wu et al. 2007, Dang et al. 2009; Kovarova et al. 2009; Bozhkov et al. 2010). Riggio et al. (2003) reported that after exposure of Danio rerio to cadmium the MT content increased around 30-fold. Wangsongsak et al. (2007) showed that hepatic expression of MT-mRNA increased significantly after $\mathrm{Cd}$ exposure of Pontius gonionotusto. This operation (synthesis of MT) reduces toxic influence of cadmium on organism and makes possible excretion. According to Roesijadi (1994) and Asagba et al. (2008), cadmium binds with MT (displacing zinc and copper) and easily forms CdMT complexes. Following release from the liver, CdMT reenters the blood stream, is filtered and reabsorbed by the renal proximal tubules. CdMT is transported into lysosomes where the complex is catabolized. This releases cadmium from the complex and free cadmium induces MT synthesis in the kidney (Klaassen and Liu 1997; Brzóska et al. 2003). Then liberated $\mathrm{Cd}$ ions are eliminated in the urine. The 
ability of tissues to synthesize MT protects organism against direct toxicity of metal; however, it causes accumulation of cadmium in organs, which results in its long half-life in organism (Bonda et al. 2007).

In conclusion, comparison of metal levels in various tissues revealed that cadmium and copper showed very high affinity to head kidney of common carp. In organs of fish exposed to copper, the content of this metal increased slightly and quickly returned to the control level, which shows that fish organism easily buffered metal level. However, concentrations of cadmium considerably increased and remained elevated for a long time which suggests that activation of mechanisms of sequestration and elimination of cadmium required more time.

Open Access This article is distributed under the terms of the Creative Commons Attribution License which permits any use, distribution, and reproduction in any medium, provided the original author(s) and the source are credited.

\section{References}

Akahori A, Jóźwiak Z, Gabryelak T, Gondko R (1999) Effect of zinc on carp (Cyprinus carpio L.) erythrocytes. Comp Biochem Physiol 123C:209-215

Allen P (1995) Chronic accumulation of cadmium in the edible tissues of Oerochromis aureus (Steindachner): modification by mercury and lead. Arch Environ Contam Toxicol 29:8-14

Al-Nagaawy AM (2008) Accumulation and elimination of copper and lead from $O$. niloticus fingerings and consequent influence on their tissue residues and some biochemical parameters. Arizona 8th international symposium on Tilapia in aquaculture. http://ag.arizona.edu/azaqua/ ista/ISTA8/ProceedingsISTA8.htm

Asagba SO, Eriyamremu GE, Igberaese ME (2008) Bioaccumulation of cadmium and its biochemical effect on selected tissues of the catfish (Clarias gariepinus). Fish Physiol Biochem 34:61-69

Bentley PJ (1991) Accumulation of cadmium by channel catfish (Ictalurus punctatus): influx from environmental solutions. Comp Biochem Physiol 99:527-529

Bettger WJ, Spry DJ, Cockell KA, Cho CY, Hilton JW (1987) The distribution of zinc and copper in plasma, erythrocytes and erythrocyte membranes of rainbow trout (Salmo gairdneri). Comp Biochem Physiol 87C:445-451

Bielmyer GK, Tomasso J, Klaine SJ (2006) Physiological responses of hybrid striped bass to aqueous copper in freshwater and saltwater. Arch Environ Contam Toxicol 50:531-538

Bonda E, Włostowski T, Krasowska A (2007) Cadmium metabolism and toxicity in human and animals. Kosmos Problemy Nauk Biologicznych 56:87-97 (In Polish)
Bozhkov A, Padalko V, Dlubovskaya V, Menzianova N (2010) Resistance to heavy metal toxicity in organisms under chronic exposure. Indian J Exp Biol 48:679-696

Brzóska MM, Kamiński M, Supernak-Bobko D, Zwierz K, Moniuszko-Jakoniuk J (2003) Changes in the structure and function of the kidneys in rats chronically exposed to cadmium I. Biochemical and histopathological studies. Arch Toxicol 77:344-352

Calta M, Canpolat Ö (2006) The comparison of three cyprinid species in terms of heavy metals accumulation in some tissues. Water Environ Res 78:548-551

Cao L, Huang W, Shan X, Ye Z, Dou S (2012) Tissue-specific accumulation of cadmium and its effects on antioxidative responses in Japanese flounder juveniles. Environ Toxicol Pharmacol 33:16-25

Carbonell G, Trazona JV (1992) Changes and accumulation patterns of copper and other essential metals due to copper sulfate treatments. In: Michel C, Alderman DJ (eds) Chemotherapy in aquaculture: from theory to reality. O.I.E, Paris, pp 487-493

Carriquiriborde P, Ronco AE (2008) Distinctive accumulation patterns of $\mathrm{Cd}(\mathrm{II}), \mathrm{Cu}(\mathrm{II})$, and $\mathrm{Cr}(\mathrm{VI})$ in tissue of the South American teleost, pejerrey (Odontesthes bonariensis). Aquat Toxicol 86:313-322

Carvalho CS, Fernandes MN (2006) Effect of temperature on copper toxicity and hematological responses in the neotropical fish Prochilodus scofa at low and high $\mathrm{pH}$. Aquaculture 251:109-117

Castano A, Carbonell G, Carballo M, Fernandez C, Boleas S, Tarazona JV (1998) Sublethal effects of repeated intraperitoneal cadmium injections on rainbow trout (Oncorhynchus mykiss). Ecotoxicol Environ Saf 41:29-35

Cavas T, Garanko NN, Arkhipchuk VV (2005) Induction of micronuclei and binuclei in blood, gill and liver cells of fishes subchronically exposed to cadmium chloride and copper sulphate. Food Chem Toxicol 43:569-574

Celechovska O, Svobodová Z, Žlábek V, Macharáčková B (2007) Distribution of metals in tissues of the common carp (Cyprinus carpio L.). Acta Vet Brno 76:93-100

Couture P, Kumar PR (2003) Impairment of metabolic capacities in copper and cadmium contaminated wild yellow perch (Perca flavescens). Aquat Toxicol 64:107-120

Coyle P, Philcox JC, Carey LC, Rofe AM (2002) Review. Metallothionein: the multipurpose protein. Cell Mol Life Sci 59:627-647

Dallinger R, Berger B, Hunziker P, Kägi JHR (1997) Metallothionein in snail $\mathrm{Cd}$ and $\mathrm{Cu}$ metabolism. Nature 388: 237-238

Dang F, Zhong H, Wang WX (2009) Copper uptake kinetics and regulation in a marine fish after waterborne copper acclimation. Aquat Toxicol 94:238-244

Dangre AJ, Manning S, Brouwer M (2010) Effects of cadmium on hypoxia-induced expression of hemoglobin and erythropoietin in larval sheepshead minnow, Cyprinodon variegatus. Aquat Toxicol 99:168-175

De Conto Cinier C, Petit-Ramel M, Faure R, Garin D (1997) Cadmium bioaccumulation in carp (Cyprinus carpio) tissues during long-term high exposure: analysis by inductively coupled plasma-mass spectrometry. Ecotoxicol Environ Saf 38:137-143 
De Smet H, Blust R (2001) Stress responses and changes in protein metabolism in carp Cyprinus carpio during cadmium exposure. Ecotoxicol Environ Saf 48:255-262

Evans RE, Brown SB, Hara TJ (1987) The fish gill: site of action and model for toxic effects of environmental pollutants. Environ Health Perspect 71:47-58

Fange R (1994) Blood cells, haemopoiesis and lymphomyeloid tissues in fish. Fish Shellfish Immunol 4:405-411

Fedeli D, Carloni M, Falcioni G (2010) Oxidative damage in trout erythrocyte in response to "in vitro" copper exposure. Marine Environ Res 69:172-177

Fijan N (2002a) Morphogenesis of blood cell lineages in channel catfish. J Fish Biol 60:999-1014

Fijan N (2002b) Composition of main haematopoietic compartments in normal and bled channel catfish. J Fish Biol 60:1142-1154

Gabbianelli R, Lupidi G, Villarini M, Falcioni G (2003) DNA damage induced by copper in erythrocytes of gilthead sea bream Sparus aurata and mollusk Scapharca inaequivalvis. Arch Environ ContamToxicol 45:350-356

Galvez F, Franklin NM, Tuttle RB, Wood CM (2007) Interactions of waterborne and dietary cadmium on the expression of calcium transporters in the gills of rainbow trout: influence of dietary calcium supplementation. Aquat Toxicol 84:208-214

Gangopadhyay K, Homechaudhuri S (2011) Descriptive characteristics of haemopoietic cell lineages in a facultative air breathing fish Clarias batrachus (L.). Turk J Zool 35: 737-746

Garofano JS, Hirshfield HI (1982) Peripheral effects of cadmium on the blood and head kidney in the brown bullhead (Ictalurus nebulosus). Bull Environ Contam Toxicol 28:552-556

Ghedira J, Jebali J, Bouraoui Z, Banni M, Guerbej H, Boussetta H (2010) Metallothionein and metal levels in liver, gills and kidney of Sparus aurata exposed to sublethal doses of cadmium and copper. Fish Physiol Biochem 36:101-107

Ghosh D, Datta S, Bhattacharya S, Mazumder S (2007) Longterm exposure to arsenic affects head kidney and impairs humoral immune responses of Clarias batrachus. Aqua Toxicol 81:79-89

Grosell MH, Hogstrand C, Wood CM (1997) Cu uptake and turnover in both $\mathrm{Cu}$-acclimated and non-acclimated rainbow trout (Oncorhynchus mykiss). Aquat Toxicol 38: 257-276

Grosell MH, Hogstrand C, Wood CM (1998) Renal Cu and Na excretion and hepatic $\mathrm{Cu}$ metabolism in both $\mathrm{Cu}-$ acclimated and non-acclimated rainbow trout (Oncorhynchus mykiss). Aquat Toxicol 40:275-291

Hamer DH (1986) Metallothionein. Annl Rev Bioch 55:913-951

Hermesz E, Abraham M, Nemcsók J (2001) Tissue-specific expression of two metallothionein genes in common carp during cadmium exposure and temperature shock. Comp Biochem Physiol 128C:457-465

Hollis L, McGeer JC, McDonald DG, Wood CM (1999) Cadmium accumulation, gill $\mathrm{Cd}$ binding, acclimation, and physiological effects during long term sublethal Cd exposure in rainbow trout. Aquat Toxicol 46:101-119

Hontela A (1998) Interrenal dysfunction in fish from contaminated sites: in vivo and in vitro assessment. Ann Rev Environ Toxicol Chem 17(1):44-48
Houston AH, Roberts WC, Kennington JA (1996) Hematological response in fish: pronephric and splenic involvements in the goldfish, Carassius auratus L. Fish Physiol Biochem 15:481-489

Huang ZY, Zhang Q, Chen J, Zhuang ZX, Wang XR (2007) Bioaccumulation of metals and induction of metallothioneins in selected tissues of common carp (Cyprinus carpio L.) co-exposed to cadmium, mercury and lead. Appl Organomet Chem 21:101-107

Isani G, Andreani G, Cocchioni F, Fedeli D, Carpene E, Falcioni G (2009) Cadmium accumulation and biochemical responses in Sparus aurata following sub-lethal Cd exposure. Ecotoxicol Environ Saf 72:224-230

Jacobson SV, Reimschuessel R (1998) Modulation of superoxide production in goldfish (Carassius auratus) exposed to and recovering from sublethal copper levels. Fish Shellfish Immunol 8:245-259

Jelovcan S, Gutschi A, Kleinhappl B, Sedlmayr P, Barth S, Marth E (2003) Effects of low concentrations of cadmium on immunoglobulin $\mathrm{E}$ production by human B lymphocytes in vitro. Toxicology 188:35-48

Jezierska B, Witeska M (2001) Metal toxicity to fish. University of Podlasie, Siedlce

Jonsson M, Part P (1998) Mechanisms for development of tolerance to heavy metals in epithelial gill cells of rainbow trout (Oncorhynchus mykiss). Mar Environ Res 46:1-5

Kalay M, Canli M (2000) Elimination of essential (Cu, Zn) and non-essential $(\mathrm{Cd}, \mathrm{Pb})$ metals from tissues of a freshwater fish Tilapia zilli. Turk J Zool 24:429-436

Karaytug S, Erdem C, Cicik B (2007) Accumulation of cadmium in the gill, liver, kidney, spleen, muscle and brain tissues of Cyprinus carpio. Ekoloji 63:16-22

Kito H, Tazawa T, Ose Y, Sato T, Ishikawa T (1982) Formation of metallothionein in fish. Comp Biochem Physiol 73C: 129-134

Kito H, Ose Y, Sato T (1986) Cadmium-binding protein (metallothionein) in carp. Environ Health Perspect 65: $117-124$

Klaassen CD, Liu J (1997) Role of metallothionein in cadmiuminduced hepatotoxicity and nephrotoxicity. Drug Met Rev 29:79-102

Kock G, Triendl M, Hofer R (1996) Seasonal patterns of metal accumulation in Arctic char (Salvelinus alpinus) from an oligotrophic Alpine lake related to temperature. Can J Fish Aquat Sci 53:780-786

Kondera E, Witeska M (2012) Cadmium-induced alternations in head kidney hematopoietic tissue of common carp. Fresenius Environ Bull 21(3a):769-773

Kovarova J, Kizek R, Adam V, Harustiakova D, Celechovska O, Svobodova Z (2009) Effect of cadmium chloride on metallothionein levels in carp. Sensors 9:4789-4803

Kraal MH, Kraak MH, De Groot C, Davids C (1995) Uptake and tissue distribution of diatery and aqueous cadmium by carp (Cyprinus carpio). Ecotoxicol Environ Saf 31:179-183

Kraemer LD, Campbell PGC, Hare L (2005) Dynamics of Cu, $\mathrm{Cd}$, and $\mathrm{Zn}$ accumulation in organs and sub-cellular fractions in field transplanted juvenile yellow perch (Perca flavescens). Environ Pollut 138:324-337

Lafuente A, González-Carracedo A, Esquifino AI (2004) Differential effects of cadmium on blood lymphocyte subsets. Biometals 17:451-456 
Leguen I, Cauty C, Odjo N, Corlu A, Prunet P (2007) Trout gill cells in primary culture on solid and permeable supports. Comp Biochem Physiol 148A:903-912

Lizardo-Daudt HM, Bains OS, Singh CR, Kennedy CJ (2007) Biosynthetic capacity of rainbow trout (Oncorhynchus mykiss) interrenal tissue after cadmium exposure. Arch Environ Contam Toxicol 52:90-96

McGeer JC, Szebedinszky C, McDonald DG, Wood CM (2000) Effects of chronic sublethal exposure to waterborne $\mathrm{Cu}, \mathrm{Cd}$ or $\mathrm{Zn}$ in rainbow trout. 1: iono-regulatory disturbance and metabolic costs. Aquat Toxicol 50:231-243

Mendez-Armenta M, Rios C (2007) Cadmium neurotoxicity. Mini review. Environ Toxicol Pharmacol 23:350-358

Moritomo T, Asakura N, Sekiya M, Ototake M, Inoue Y, Nakanishi T (2004) Cell culture of clonal ginbuna crucian carp hematopoietic cells: differentiation of cultured cells into erythrocytes in vivo. Dev Comp Immunol 28:863-869

Murray-Gulde CL, Heatley JE, Schwartzman AL, Rogers JH Jr (2002) Algicidal effectiveness of Clearigate, Cutrine-Plus, and copper sulfate and margins of safety associated with their use. Arch Environ Contam Toxicol 43:19-27

Olowoyo JO, Mdakane STR, Okedeyi OO (2011) Comparing the levels of trace metal from two fish species harvested from treated waste water in Pretoria, South Africa. Pak J Biol Sci 14:688-692

Oprządek K, Syrocka K, Olszewska E, Szmitkowska M, Borkowska M (2006) Minerals and trace elements levels in some soy-based food products from Poland. Polish J Environ Stud 15(2a):444-447

Oprządek K, Górska A, Olszewska E (2010) Trace elements: from raw cow milk to dairy products. Fresenius Environ Bull 19(4):585-588

Panchanathan J, Vattapparumbil IP (2006) Patterns of cadmium accumulation in selected tissues of the catfish Clarias batrachus (Linn.) exposed to sublethal concentration of cadmium chloride. Veterinarski Arhiv 76:167-177

Pelgrom SMGJ, Lamers LPM, Lock RAC, Balm PHM, Wendelaar Bonga SE (1995) Interactions between copper and cadmium modify metal organ distribution in mature tilapia, Oreochromis mossambicus. Environ Pollut 90:415-423

Petanova J, Fučíková T, Bencko V (2000) Influence of cadmium and zinc sulphates on the function of human T lymphocytes in vitro. Cent Eur J Public Health 8:137-140

Radhakrishnan MV (2010) Immunological effect of cadmium in Heteropneustes fossilis Bloch. Global Veterinaria 4:544-547

Ramesh M, Senthil Kumaran S, Kavith C, Saravanan M, Mustafa A (2007) Primary stress responses of common carp, Cyprinus carpio, exposed to cooper toxicity. Acta Ichthyol Piscat 37(2):81-85

Rauf A, Javed M, Ubaidullah M (2009) Heavy metal levels in three major carps (Calta calta, Labeo rohita and Cirrhina mrigala) from the river Ravi, Pakistan. Pak Vet J 29:24-26

Reynders H, van der Ven K, Moens LN, van Remortel P, De Coen WM, Blust R (2006) Patterns of gene expression in carp liver after exposure to a mixture of waterborne and dietary cadmium using a custom-made microarray. Aquat Toxicol 80:180-193

Riggio M, Filosa S, Parisi E, Scudiero R (2003). Changes in zinc, copper and metallothionein contents during oocyte growth and early development of the teleost Danio rerio (zebrafish). Comp Biochem Physiol 135C:191-196
Roesijadi G (1994) Metallothionein induction as a measure of response to metal exposure in aquatic animals. Environ Health Perspect 102:91-96

Roesijadi G, Hansen KM, Unger E (1996) Cadmium-induced metallothionein expression during embrionic and early larval development of the mollusc Crassostrea virginica. Toxicol Appl Pharmacol 140:356-363

Romano N, Ceccariglia S, Mastrolia L, Mazzini M (2002) Cytology of lymphomyeloid head kidney of Antarctic fishes Trematomus bernacchii (Nototheniidae) and Chionodraco hamatus (Channicthyidae). Tissue Cell 34: 63-72

Rombout JHWM, Huttenhuis HBT, Picchietti S, Scapigliati G (2005) Phylogeny and ontogeny of fish leucocytes. Fish Shellfish Immunol 19:441-455

Romeo M, Bennani N, Gnassia-Barelli M, Lafaurie M, Girard JP (2000) Cadmium and copper display different responses towards oxidative stress in the kidney of the sea bass Dicentrarchus labrax. Aquat Toxicol 48:185-194

Rose WL, Nisbet RM, Green PG, Norris S, Fan T, Smith EH, Cherr GN, Anderson SL (2006) Using an integrated approach to link biomarker responses and physiological stress to growth impairment of cadmium-exposed larval topsmelt. Aquat Toxicol 80:298-308

Saxena MP, Gopal K, Jones W, Ray PK (1992) Immune responses to Aeromonas hydrophila in cat fish (Heteropneustis fossillis) exposed to cadmium and hexachlorocyclohexane. Bull Environ Contam Toxicol 48:194-201

Schultz R, Peters EL, Newman MC (1996) Toxicokinetics and disposition of inorganic mercury and cadmium in channel catfish after intravascular administration. Toxicol Appl Pharmacol 140:39-50

Shalaby AME (2007) Effect of EDTA on toxicity reduction of cadmium in relation to growth, some haematological and biochemical profiles of nile tilapia (Oreochromis niloticus). J Fish Aquat Sci 2:100-109

Shao X, Liu W, Xu W, Lu K, Xia W, Jiang Y (2010) Effects of dietary copper sources and levels on performance, copper status, plasma antioxidant activities and relative copper bioavailability in Carassius auratus gibelio. Aquaculture 308:60-65

Singh J, Kant K, Sharma HB, Rana KS (2008) Bioaccumulation of cadmium in tissues of Cirrihna mrigala and Catla catla. Asian J Exp Sci 22:411-414

Soengas JL, Agra-Lago MJ, Carballo B, Ander's MD, Veira JAR (1996) Effect of an acute exposure to sublethal concentrations of cadmium on liver carbohydrate matabolisms of Atlantic salmon (Salmo salar). Bull Environ Contam Toxicol 57:625-631

Som M, Kundu N, Bhattacharyya S, Homechaudhuri S (2009) Evaluation of hemopoietic responses in Labeo rohita Hamilton following acute copper toxicity. Toxicol Environ Chem 91:87-98

Tao S, Liu C, Dawson R, Long A, Xu F (2008) Uptake of cadmium adsorbed on particulates by gills of goldfish (Carassius auratus). Ecotoxicol Environ Saf 47:306-313

Thophon S, Kruatrachue M, Upatham ES, Pokethitiyook P, Sahaphongb S, Jaritkhuan S (2003) Histopathological alterations of white seabass, Lates calcarifer, in acute and subchronic cadmium exposure. Environ Pollut 121: 307-320 
Verbost PM, Van Rooij J, Flik G, Lock RAC, Wendelaar Bonga SE (1989) The movement of cadmium through freshwater trout branchial epithelium and its interference with calcium transport. J Exp Biol 145:185-197

Vinodhini R, Narayanan M (2008) Bioaccumulation of heavy metals in organs of fresh water fish Cyprinus carpio (Common carp). Int J Environ Sci Tech 5:179-182

Walker MP (2000) Cadmium carcinogenesis in review. J Inorg Bichem 7:241-244

Wangsongsak A, Utarnpongsa S, Kruatrachue M, Ponglikitmongkol M, Pokethitiyook P, Sumranwanich T (2007) Alterations of organ histopathology and metallothionein mRNA expression in silver barb, Puntius gonionotus during subchronic cadmium exposure. J Environ Sci 19(11): 1341-1348

Wendelaar Bonga SE (1997) The stress response in fish. Physiol Rev 77:591-625

Weyts FAA, Cohen N, Flik G, Verburg-Van Kemenade BML (1999) Interactions between the immune system and the hypothalamo-pituitary-interrenal axis in fish. Fish Shellfish Immunol 9:1-20
Witeska M, Kondera E, Lipionoga J, Jastrzębska A (2010) Changes in oxygen consumption rate and red blood parameters in common carp Cyprinus carpio L. after acute copper and cadmium exposures. Fresenius Environ Bull 19:115-122

Witeska M, Kondera E, Szczygielska K (2011) The effects of cadmium on common carp erythrocyte morphology. Pol J Environ Stud 20:783-788

Wittman R, Hu H (2002) Cadmium exposure and nephropathy in a 28-year-old female metals worker. Environ Health Perspect 110:1261-1266

Woodling JD, Brinkman SF, Horn BJ (2001) Nonuniform accumulation of cadmium and copper in kidneys of wild brown trout (Salmo trutta) population. Arch Environ Contam Toxicol 40:381-385

Wu SM, Shih MJ, Ho YC (2007) Toxicological stress response and cadmium distribution in hybrid tilapia (Oreochromis sp.) upon cadmium exposure. Comp Biochem Physiol $145 \mathrm{C}: 218-226$ 